\title{
Morphological and morphometric studies of the antennal sensilla from two populations of Atta robusta (Borgmeier 1939) (Hymenoptera: Formicidae)
}

\author{
Euzébio*, DE., Martins, GF. and Fernandes-Salomão, TM. \\ Departamento de Biologia Geral, Universidade Federal de Viçosa - UFV, CEP 36570-000, Viçosa, MG, Brazil \\ *e-mail:deniseeuzebio@yahoo.com.br \\ Received June 6, 2012 - Accepted August 23, 2012 - Distributed August 31, 2013
}

(With 3 figures)

\begin{abstract}
The ant Atta robusta is endemic to the "restinga" ecosystems where it has an important role in the dynamics of seed dispersal. Despite its importance, A. robusta is considered a threatened species. In this study we analyzed the antennal sensory organs of two different populations of A. robusta (from the cities of São Mateus and Maricá in in Espírito Santo and Rio de Janeiro States, respectively) using a scanning electron microscope (SEM). SEM revealed different types of sensilla in the $A$. robusta antennae, i.e., curved and straight trichoid, basiconic, ampullacea and coeloconic, which were highly abundant found in the distal flagellomeres (F) compared with other antenna regions. There were differences in samples collected from two locations in terms of the sensilla number and length. The average numbers of straight and curved trichoid sensillae numbers were different in F9 and F8, respectively, while the average length of the curved trichoid sensilla was only different in F9. These variations in sensory organs between two populations of $A$. robusta may indicate an adaptation of this species to different environmental conditions. The number of straight trichoid sensilla was only significantly different in F9.
\end{abstract}

Keywords: Attini, scanning electron microscopy, sensory organs.

\section{Estudo morfológico e morfométrico das sensilas antenais de Atta robusta (Borgmeier 1939) (Hymenoptera: Formicidae)}

\section{Resumo}

Atta robusta é uma espécie de formiga endêmica, com papel importante na dinâmica dos ecossistemas de restinga. Apesar de sua importância como dispersora de sementes nesse tipo de ecossistema, essa espécie encontra-se ameçada de extinção. O presente trabalho lançou mão da microscopia eletrônica de varredura (MEV) para descrever as sensilas antenais de $A$. robusta e investigar diferenças entre sensilas antenais dessa espécie em indivíduos coletados em localidades diferentes, nos municípios de São Mateus (Estado do Espírito Santo) e Maricá (Estado do Rio de Janeiro). Diferentes tipos de sensilas como tricoideas retas e curvadas, basicônicas, ampuláceas e celocônicas foram encontradas nas antenas, sendo que todas são mais numerosas no flagelomero nove (F9) ou mais distal. Houve diferença em número e em comprimento das sensilas tricoideas retas e curvatas em F8 e F9 entre os indivíduos das duas localidades. Os números médios das sensilas tricoides retas e curvadas foram diferentes para os F9 e F8, respectivamente, enquanto que o comprimento médio das sensilas tricoides curvadas foi diferente para o F9. Essa variação na quantidade de sensilas antenais entre as populações é, possivelmente, uma plasticidade fenotípica, característica importante para a adaptação de espécies a variações ambientais. Esse trabalho representa um estudo preliminar na tentativa de se estudar a variação nos órgãos sensoriais entre diferentes populações de $A$. robusta.

Palavras-chave: Attini, microscopia eletrônica de varredura, órgão sensorial.

\section{Introduction}

Ants have complex social organization and their colonies may be formed of millions of individuals from different castes (Evison and Ratnieks, 2007). This organization is facilitated by communication using chemical signals, which are received and processed by their brain that can result in mechanical responses (Reviewed by
Chapman, 1998). Many different types of chemical signals can be sensed from the environment (Billen, 2006), which are received by sensorial structures or sensilla (Kleineidam et al., 2000; Ozaki et al., 2005).

Sensilla are found in different regions of insects including the antennae, including social insects, such as bees (Silva-de-Moraes and Cruz-Landim, 1972). There 
are also several different types of sensilla, which are classified according to their shape and size. Generally speaking, the most common types of sensilla of hymenopterans are trichoid and basiconic, which are involved with mechanical and chemical perception (Renthal et al., 2003; Ozaki et al., 2005; Rocha et al., 2007; Spaethe et al., 2007; Onagbola et al., 2008).

The morphology and abundance of antennal sensilla may vary depending on the insect family (Hashimoto, 1991), subspecies (Stort and Moraes-Alves, 1999), caste (Nakanishi et al., 2009), and developmental stage (Silva et al., 2010). The types and size of sensilla may also vary depend upon the geographical distribution of insects. For example, different patterns of trichoid and basiconic sensilla numbers were described in different populations of Rhodnius prolixus (Stål, 1859) (Heteroptera, Reduviidae, Triatominae) sampled from east and west of the Andes Mountains (Esteban et al., 2005). These differences suggest that the geographically isolation of the populations was associated with the numbers of antennal sensilla (Esteban et al., 2005).

The genus Atta are known as leaf-cutting ants. This genus is widely distributed throughout the American continent where it is considered a major agricultural pest. They subsist mostly on fungus they cultivate on leaf tissues. Atta robusta is ecologically important as a key seed disperser in the restingas (coastal sand-dune habitats) of the Brazilian states of Rio de Janeiro and Espírito Santo (Teixeira et al., 2004; Teixeira, 2007).

The genus Atta includes leaf-cutting ants and is widely distributed throughout the American continent where it is considered a major agricultural pest, subsisting mostly on fungus they cultivate on leaf tissues. On the other hand, several species of Atta are ecologically important as seed dispersers. For example, Atta robusta is ecologically important as a key seed disperser in the restingas (coastal sand-dune habitats) of the Brazilian states of Rio de Janeiro and Espírito Santo (Teixeira et al., 2004; Teixeira, 2007).

Despite the importance of $A$. robusta in the restingas, it is considered to be a threatened species (Machado et al., 2003). Several aspects of the ecology of $A$. robusta have been studied (Teixeira et al., 2004; Teixeira, 2007), but there have been no previous studies of the morphology of A. robusta sensorial organs. Thus, the current study used scanning electron microscopy (SEM) to investigate comparatively the microanatomy and distribution of antennal sensilla in two different populations of $A$. robusta for the first time. The results provided an overview of the types, size and number of the antennal sensillae of this species, showing that characteristics of these structures can vary depending on the geographical regions.

\section{Materials and Methods}

\subsection{Samples}

Adult workers of $A$. robusta were collected from an underground nest in the restinga near the city of São Mateus (SM: Espírito Santo State, Brazil) (3974'60" S, $\left.18^{\circ} 68^{\prime} 23^{\prime \prime} \mathrm{W}\right)$ and another nest in the restinga near the city of Maricá (M: Rio de Janeiro State, Brazil) (42 $88^{\prime} 92^{\prime \prime}$ S, $22^{\circ} 94 ' 58^{\prime}$ W). Samples were placed in $70 \%$ ethanol and transferred to Laboratório de Biologia Celular e Molecular at Universidade Federal de Viçosa, Viçosa, MG, Brazil.

\subsection{SEM}

The right antenna was removed from ten $A$. robusta workers from each population (SM and M) for SEM analysis. The antennae were washed with PBS (phosphate buffered saline) and dehydrated in an ascending series of acetone (50-100\%). They were then subjected to critical point drying, mounted on aluminum stubs, and metallized using a sputter coating device. Samples were observed using a LEO VP1430 SEM at Núcleo de Microscopia e Microanálise (Universidade Federal de Viçosa).

\subsection{Analysis of the antenna}

Measurements of the antennal scape, pedicel and flagellum were taken from $A$. robusta workers antenna. In addition, sensilla from the dorsal surface of the last three flagellomeres (F7, F8, and F9) were classified according to the morphological criteria specified by Silvade-Moraes and Cruz-Landim (1972) and papers therein. These three flagellomers were choose based in the previous assumption that sensilla are concentrated in these insect antennal parts that are also the most exposed (Villela et al., 2005). Finally, the straight and curved trichoid sensilla (the most abundant) were counted.

\subsection{Statistical analyses}

Sensilla were counted in three antennal areas (14.870 $\mathrm{m}^{2} /$ flagellomere) using the Adobe Photoshop CS program and the average count from these three areas was considered for statistical analysis. We measured the length of 20 straight trichoid sensilla in the three last flagellomeres (F7, F8 and F9) using the program Image-Pro Plus (Media Cybernetics). Data were tested by analysis of variance (ANOVA) at $p<5 \%$, using the SAEG program.

\section{Results}

SEM analysis showed that the antenna of $A$. robusta worker was geniculate and it was composed of three basic segments, i.e., the scape, pedicel, and flagellum, which had average lengths of $3.13 \mathrm{~mm}, 0.45 \mathrm{~mm}$ and $3.74 \mathrm{~mm}$, respectively. The flagellum is formed of nine flagellomeres (F1-F9), which had an average length of $0.38 \mathrm{~mm}$, with the exception of the last one where the average was $0.67 \mathrm{~mm}$ (Figure 1A). 
A detailed inspection of the antenna dorsal surfaces of the A. robusta workers from two different populations [São Mateus (SM) and Maricá (M)] indentified several different types of sensilla, which are described as follows: (1) Trichoid: characterized by a tapered end, with two subtypes, i.e. (1.1) straight trichoid was the most common, which was slightly curved and more abundant in the last flagellomere (F9); and (1.2) long curved trichoid were also abundant in F9 and they had a curved end

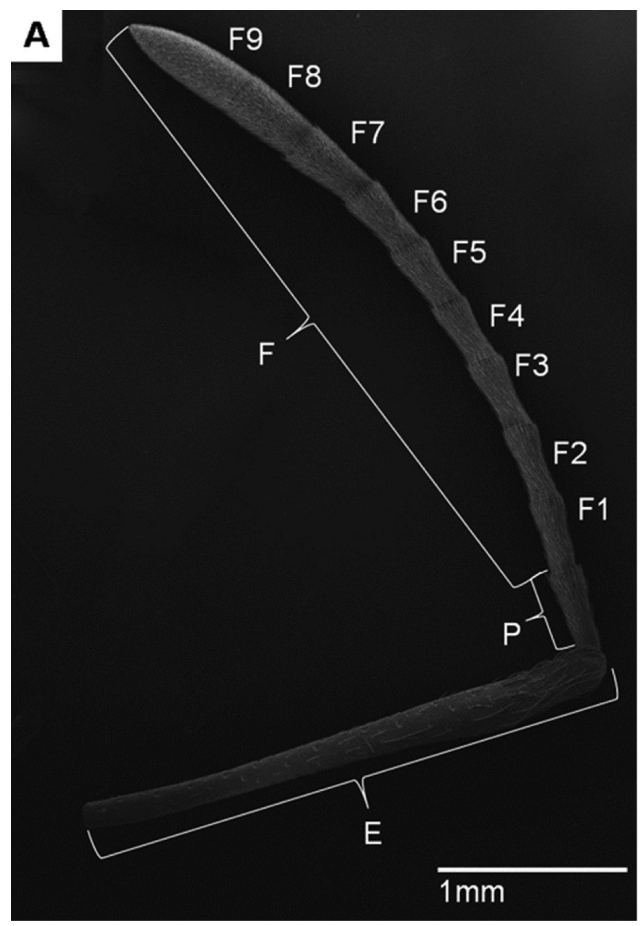

(Figure 1B); (2) Basiconic: were less common and they had a thick base with no tapered end, while they were thicker than the trichoid sensilla. We refer to them as digitiform (finger-like) sensilla; (3) Ampullacea: with a prominent elliptical depression and a central opening and (4) Coeloconic: with small round openings and less prominent edges compared with ampullacea. Ampullacea and coeloconic sensilla were found exclusively at the end of F9 (Figure 2).

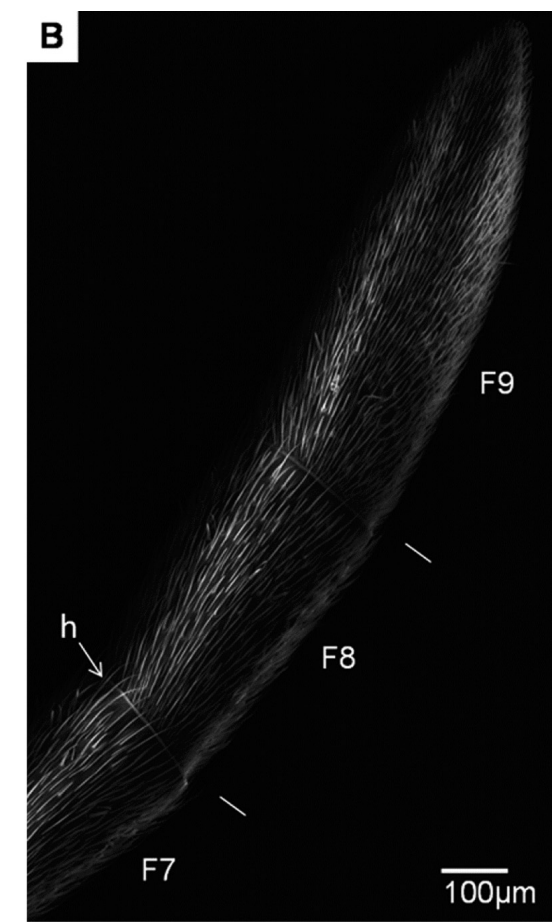

Figure 1 - [A] SEM image showing a general view of the dorsal surface of the $A$. robusta antenna: scape (E), pedicel (P), and flagellum (F). [B] Detailed view of the final three flagellomeres (F7, F8 and F9), which are covered by hair-like structures (h) that correspond to antennal sensilla.

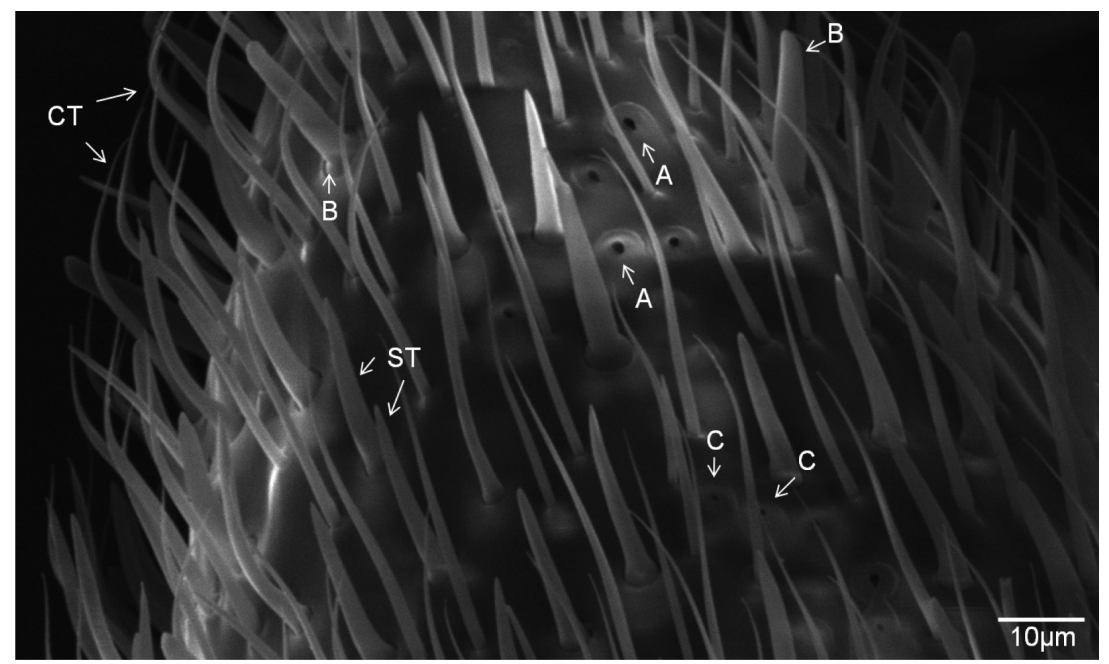

Figure 2 - SEM image showing details of the tip of F9 of the antenna of $A$. robusta including different types of sensilla: (CT) curved and (ST) straight trichoid, (B) basiconic, (A) ampullacea, and (C) coeloconic. 
The average numbers of straight trichoid sensilla per area $\left(14.870 \mu \mathrm{m}^{2} /\right.$ flagellomere $)$ were as follows: $\mathrm{F} 7=3.2$ $\pm 0.32, \mathrm{~F} 8=9.1 \pm 0.35$, and $\mathrm{F} 9=19.1 \pm 1.32$ in individuals from SM; and $\mathrm{F} 7=2.5 \pm 0.24, \mathrm{~F} 8=8.5 \pm 0.41$ and $\mathrm{F} 9=15.7 \pm 0.64$ in individuals from $\mathrm{M}$. The number of sensilla was only different in F9 $(\mathrm{F}=0.0335, \mathrm{p}<0.05)$ (Figure 3A).

The average length of the straight trichoid sensilla were: $\mathrm{F} 7=27.1 \pm 0.3, \mathrm{~F} 8=26.7 \pm 0.26$, and F9 $=25.4 \pm$ $0.33 \mu \mathrm{m}$ in individuals from SM; and F7 $=26.6 \pm 0.24$, $\mathrm{F} 8=26.6 \pm 0.28$, and $\mathrm{F} 9=25.5 \pm 0.4 \mu \mathrm{m}$ in individuals from $M$. Thus, the lengths of the sensilla did not differ
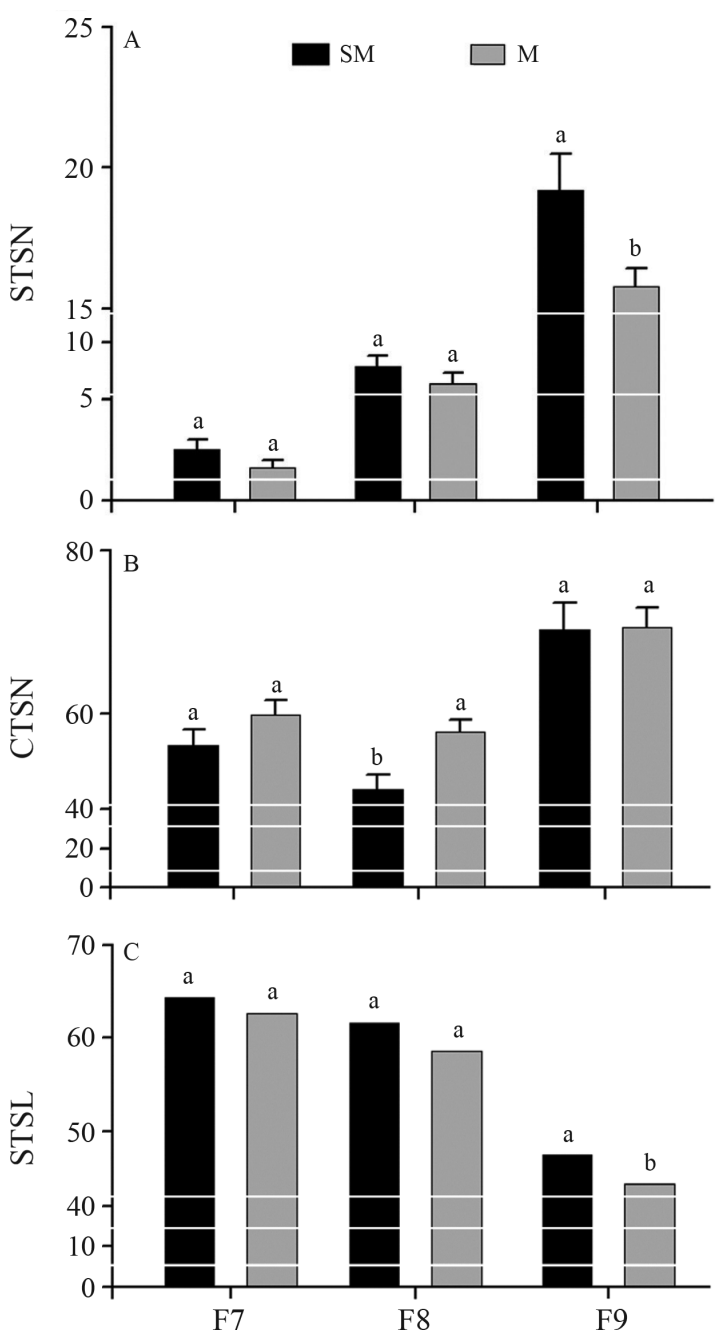

Figure 3 - Antennal sensilla counts for areas $\left(14.870 \mu \mathrm{m}^{2} /\right.$ flagellomere) and lengths of the flagellomeres (F7, F8, and F9) in A. robusta. [A] Straight trichoid sensilla numbers (STSN); [B] curved trichoid sensilla numbers (CTSN); [C] straight trichoid sensilla lengths (STSL). SM: individuals from São Mateus (Espírito Santo State); M: individuals from Maricá (Rio de Janeiro State). Columns with the same letter did not differ statistically according to the ANOVA, $\mathrm{p}<5 \%$. from F7-F9 between the two populations (data not shown).

The average numbers of curved trichoid sensilla per area $\left(14.870 \mu \mathrm{m}^{2} /\right.$ flagellomere $)$ were: $\mathrm{F} 7=56.0 \pm 1.90$, $\mathrm{F} 8=50.8 \pm 1.71$, and $\mathrm{F} 9=70.2 \pm 3.35$ in individuals from $\mathrm{SM}$; and $\mathrm{F} 7=59.8 \pm 1.73, \mathrm{~F} 8=57.7 \pm 1.45$, and $\mathrm{F} 8=70.5$ \pm 2.39 in individuals from $M$. Thus, the sensilla numbers were only different in F8 ( $F=0.00644, \mathrm{p}<0.05)$ (Figure 3B).

The average length of the curved trichoid sensilla were: $\mathrm{F} 7=64.3 \pm 1.25, \mathrm{~F} 8=61.5 \pm 1.22$, and F9 $=47.5 \pm$ $0.93 \mu \mathrm{m}$ in individuals from SM; and F7 $=62.6 \pm 1.05$, $\mathrm{F} 8=58.5 \pm 0.96$, and F9 $=44.3 \pm 0.82 \mu \mathrm{m}$ in individuals from $\mathrm{M}$. The sensilla lengths were only different in $\mathrm{F} 9$ $(\mathrm{F}=0.02148, \mathrm{p}<0.05)$ (Figure 3C).

\section{Discussion}

Sensilla are sensorial organs and several are associated with communication among social insects and their interaction with the environment (Billen, 2006). This study is the first attempt to describe and provide a comparative analysis of the antennal sensorial organs from $A$. robusta, which is an important seed disperser, from two restingas in the states of Rio de Janeiro and Espírito Santo (Brazil).

Different types of sensilla were described using SEM in the last three flagellomeres of $A$. robusta, i.e., curved and straight trichoids, basiconic, ampullacea, and coeloconic. This antennal sensilla diversity has been commonly reported and it is well characterized in other species of ants (Kleineidam et al., 2000; Ruchty et al., 2009; Nakanishi et al., 2009; Siddiqui et al., 2010). They represent a fraction of the many sensilla that have been previously described in other hymenopterans (i.e., trichoid, basiconic, coeloconic, chaetic, ampullacea, campaniform, and placoid) (Hashimoto, 1990; Renthal et al., 2003; Marques-Silva et al., 2006).

Curved and straight trichoid sensilla were the most abundant in $A$. robusta antennae, which are usually considered as mechanoreceptors (Baaren et al., 2007). The basiconic sensilla were the least abundant, although they were found more frequently in F9 compared with F7 and F8, while they are typically found only in female ants (Nakanishi et al., 2009). The ampullacea sensilla were found at the end of the final flagellomere (F9) on $A$. robusta antennae and their morphology was markedly different from other sensilla types. They were very small sensory hair-like structures contained in a cuticular depression, or ampoule, which was connected to the external environment via a cuticular duct (Kleineidam et al., 2000). The ampullacea sensilla of Atta are considered to be associated with the detection of the $\mathrm{CO}_{2}$ concentration within nests (Kleineidam et al., 2000). The coeloconic sensilla were also found exclusively on F9 and they are associated with thermoperception in Atta vollenweideri (Forel, 1893) (Formicidae) (Ruchty et al., 2009). 
Phenotypic polymorphisms, such as variations in body size, have been reported in populations of ants from different geographical regions, e.g., Pheidole morrisi (Formicidae) (Yang et al., 2004). However, differences in the sensorial organs of a single ant species from different geographical regions remains little explored. The variation in the length and number of trichoid sensilla between the two populations we studied has also been reported for other insects, e.g., Triatominae (Villela et al., 2005). This variation may be attributable to adaptations to the specific sensorial requirements of different habitats and geographical distribution (Catalá et al., 2004). It might also be related to phenotypic plasticity, because genetically similar organisms may have different phenotypes depending on environmental variables (Carreira et al., 2006; Marteleto et al., 2009).

Although both of the study populations of $A$. robusta came from the restingas, they differed in terms of their antennal sensorial organs. The curved trichoid sensilla (considered to be mechanoreceptors) were larger and less abundant in F7 and F9, respectively, in samples from $\mathrm{SM}$, whereas the straight trichoid sensilla were less numerous in F9. These differences could be a result of the adaptation of these insects to different environmental conditions, which is commonly found with other insect body parts (Carreira et al., 2006; Marteleto et al., 2009). However, this needs to be clarified in future studies.

In spite of the difference observed in the A. robusta sensillae number and size, our preliminary results based on mtDNA sequencing suggested that despite the large geographical distance $(707 \mathrm{~km})$ between these two $A$. robusta populations they had low genetic variability (Euzébio et al. unpublished data). So, these morphological differences in the sensorial organs might represent phenotypic plasticity (Catalá et al., 2004, Carreira et al., 2006, Marteleto et al., 2009), that could result from different environment conditions these two A. robusta populations are submitted.

The antennal sensilla are important sensorial organs for insect communication and survival, and they are in constant contact with the environment (Iwasaki et al., 1995; Nakanishi et al., 2009). The environmental conditions may affect living organisms differently, so it is important to develop conservation plans for this species where it is considered threatened. Atta robusta is endemic to the restingas, which are threatened by deforestation and possible housing development. The Brazilian sea coast has different types of restingas, which they are not homogeneous in terms of their flora and fauna (Pereira et al., 2001; Afonso et al., 2007; Rocha et al., 2005). The preservation of this ecosystem is strategically important for A. robusta and other species that live in this environment, which is of social and economic importance to human populations.

\section{Acknowledgments}

The authors are grateful to the Fundação de Amparo à Pesquisa do Estado de Minas Gerais (FAPEMIG),
Coodenação de Aperfeiçoamento de Pessoal de Nível Superior (CAPES), and Conselho Nacional de Desenvolvimento Científico e Tecnológico (CNPq).

\section{References}

AFONSO, AS., MEDEIROS, AS., NUNES, CS., RODRIGUES, GA., NUNES, RS., TAVARES, LFM. and CONDE, MMS., 2007. Florística da vegetação arbustiva aberta na Restinga da Marambaia, RJ. Revista Brasileira de Biociências vol. 5, p. 450-452.

BAAREN, J., BOIVIN, G., BOURDAIS, D. and ROUX O., 2007. Antennal sensilla of hymenopteran parasitic wasps: variations linked to host exploitation behavior. In MENDEZ-VILAS, A. and DÍAZ, J. (Eds.). Modern research and educational topics in microscopy: Applications in biology and medicine. Badajoz: Formatex. p. 345-352. vol. 1 .

BILLEN, J., 2006. Signal variety and communication in social insects. Proceedings of the section experimental and applied entomology, vol. 17, p. 9-25.

CARREIRA VP., SOTO, IM., HASSON, E. and FANARA JJ., 2006. Patterns of variation in wing morphology in the cactophilic Drosophila buzzatii and its sibling D. koepferae. Journal of Evolutionary Biology, vol. 19, p. 1275-1282.

CATALÁ, SS., MAIDA, DM., CARO-RIAÑO, H., JARAMILLO, N. and MORENO, J., 2004. Changes associated with laboratory rearing in antennal sensilla patterns of Triatoma infestans, Rhodnius prolixus, and Rhodnius pallescens (Hemiptera, Reduviidae, Triatominae). Memórias do Instituto Oswaldo Cruz, vol. 99, p. 25-30.

CHAPMAN RF., 1998. The insects: structure and function. Cambridge: Cambridge University Press. 770 p.

DIEHL, E., SANHUDO, CED. and DIEHL-FLEIG, E., 2004. Ground-dwelling ant fauna of sites with high levels of copper. Brazilian Journal of Biology, vol. 64, p. 33-39.

ESTEBAN, L., ANGULO, VM., FELICIANGELI, MD., and CATALÁ, S., 2005. Analysis of antennal sensilla patterns of Rhodnius prolixus from Colombia and Venezuela. Memórias do Instituto Oswaldo Cruz, vol. 100, p. 909914.

EVISON, SF. and RATNIEKS, FW., 2007. New role for majors in Atta leafcutter ants. Ecological Entomology, vol. 32, p. 451-454.

HASHIMOTO, Y., 1990. Unique features of sensilla on the antennae of Formicidae (Hymenoptera). Applied Entomology and Zoology, vol. 25 no. 4, p. 491-501.

HASHIMOTO, Y., 1991. Phylogenetic study of the family Formicidae based on the sensillum structures on the antennae and labial palpi (Hymenoptera, Aculeata). Japanese journal of entomology, vol. 59, p. 125-140.

HEINZE, J., FOITZIK, S., FISCHER, B., WANKE, T. and KIPYATKOV, VE., 2003. The significance of latitudinal variation in body size in a holarctic ant, Leptothorax acerorum. Ecography, vol. 26, p. 349-355.

IWASAKI, M., ITOH, T., YOKOHARI, F. and TOMINAGA, Y., 1995. Identification of antennal hygroreceptive sensillum and other sensilla of firefly, Luciola cruciata. Zoological Science, vol. 12, p. 725-732.

KLEINEIDAM, C., ROMANI, R., TAUTZ, J. and ISIDORO, N., 2000. Ultrastructure and physiology of the $\mathrm{CO}_{2}$ sensillum ampullaceum in the leaf-cutting ant Atta sexdens. Arthropod Structure \& Development, vol. 29, p. 43-55. 
MACHADO, ABM., BRESCOVIT, AD., MIELKE, OH., CASAGRANDE, M., SILVEIRA, FA., OHLWEILER, FP., ZEPPELINI, DMM. and WIELOCH, AH., 2003. Invertebrados terrestres: Panorama geral dos invertebrados terrestres ameaçados de extinção. In MACHADO, ABM., DRUMMOND, GM. and PAGLIA, AP. Livro vermelho da fauna brasileira ameacada de extinca o. Brasília: MMA. 193 p.

MARQUES-SILVA, S., MATIELLO-GUSS, CP., DELABIE, JHC., MARIANO CSF., ZANUNCIO JC. and SERRÃO JE., 2006. Sensilla and secretory glands in the antennae of a primitive ant: Dinoponera lucida (Formicidae: Ponerinae). Microscopy Research and Technique, vol. 69, p. $885-890$.

MARTELETO, PB., LOMÔNACO, C. and KERR, W. 2009. Respostas fisiológicas, morfológicas e comportamentais de Zabrotes subfasciatus (Boheman) (Coleoptera: Bruchidae) associadas ao consumo de diferentes variedades de feijão (Phaseolus vulgaris). Neotropical Entomology, vol. 38, p. 178-185.

MIZUNAMI, M., YAMAGATA, N. and NISHINO H., 2010. Alarm pheromone processing in the ant brain: an evolutionary perspective. Frontiers in Behavioral Neuroscience, vol. 4, p. 1-9.

NAKANISHI, A., NISHINO, H., WATANABE, H., YOKOHARI, F. and NISSHIKAWA, M., 2009. Sex-specific antennal sensory system in the ant Camponotus japonicus: structure and distribution of sensilla on the flagellum. Cell \& Tissue Research, vol. 338, p. 79-97.

ONAGBOLA, EO., MEYER, WL., BOINA, DR. and STELINSKI, LL., 2008. Morphological characterization of the antennal sensilla of the Asian citrus psyllid, Diaphorina citri Kuwayama (Hemiptera: Psyllidae), with reference to their probable functions. Micron, vol. 39, p. 1184-1191.

OZAKI, M., WADA-KATSUMATA, A., FUJIKAWA, K., IWASAKI, M., YOKOHARI, F., SATOJI, Y. NISIMURA, T. and YAMAOKA, R., 2005. Ant nestmate and non-nestmate discrimination by a chemosensory sensillum. Science, vol. 309, p. 311-313.

PEREIRA, MCA., ARAUJO, DSD. and PEREIRA, OJ., 2001. Estrutura de uma comunidade arbustiva da restinga de Barra de Maricá - RJ. Revista Brasileira de Botânica, vol. 24, p. 273-281.

RENTHAL, R., VELASQUEZ, D., OLMOS, D., HAMPTON, J. and WERGIN, WP., 2003. Structure and distribution of antennal sensilla of the red imported fire ant. Micron, vol. 34, p. 405-413.

ROCHA, CFD., VAN SLUYS, M., BERGALLO, HG. and ALVES, MAS., 2005. Endemic and threatened tetrapods in the restingas of the biodiversity corridors of Serra do mar and of the central da Mata Atlântica in eastern Brazil. Brazilian Journal of Biology, vol. 65, p. 159-168.

ROCHA, L., MOREIRA, GRP. and REDAELLI, LR., 2007. Systematics morphology and distribution of antennal sensilla of Gryon gallardoi (Brethes) (Hymenoptera: Scelionidae) females. Neotropical Entomology, vol. 36, p. 721-728.

RUCHTY, M., ROMANI, R., KUEBLER, LS., RUSCHIONI, S., ROCES, F., ISIDORO, N. and KLEINEIDAM, CJ., 2009. The thermo-sensitive sensilla coeloconica of leafcutting ants (Atta vollenweideri). Arthropod Structure \& Development, vol. 38, p. 195-205

SIDDIQUI, MI., MASHALY, AMA., AHMED, AM., AL-MEKHLAFI, FA. and AL-KHALIFA, MS., 2010, Ultrastructure of antennal sensillae of the samsum ant, Pachycondyla sennaarensis (Hymenoptera:Formicidae). African Journal of Biotechnology, vol. 9, p. 6956-6962.

SILVA, CCA., CAPDEVILLE, G., MORAES, MCB., FALCÃO, R., SOLINO, LF. LAUMANN, RA., SILVA, JP. and BORGES, M., 2010. Morphology, distribution and abundance of antennal sensilla in three stink bug species (Hemiptera: Pentatomidae). Micron, vol. 41, p. 289300.

SILVA-DE-MORAES, RLM. and CRUZ-LANDIM, C., 1972. Estudo comparativo de órgãos sensoriais em abelhas com diferentes tipos de comunicação. Brazilian Journal of Biology, vol. 32, p. 185-196.

SPAETHE, J., BROCKMANN, A. HALBIG, C. and TAUTZ J., 2007. Size determines antennal sensitivity and behavioral threshold to odors in bumblebee workers. Naturwissenschaften, vol. 97, p. 733-739.

STORT, AC. and MORAES-ALVES, MMB., 1999. Differences in the number of antennal sensory structures of males of three honey bee types. Revista Brasileira de Biologia, vol. 59, p. 161-166.

TEIXEIRA, MC. (2007). Dispersão de sementes por Atta robusta Borgmeier 1939 (Hymenoptera: Formicidae) nas restingas da Ilha de Guriri-ES. Viçosa: Universidade Federal de Viçosa. 72 p.Tese de Doutorado.

TEIXEIRA, MC., SCHOEREDER, JH. and LOUZADA, JNC. (2004). Occurrence of Atta robusta Borgmeier (Hymenoptera: Formicidae) in the North of Espírito Santo State, Brazil. Neotropical Entomology, vol. 33, p. 265266.

VILLELA, MM., CATALÁ S., JUBERG, J., SILVA, IG. and DIAS J.C.P. (2005). Patterns of antennal sensilla of Panstrongylus megistus from three Brazilian states. Memórias do Instituto Oswaldo Cruz, vol. 100, p. 699702 .

YANG, AS., MARTIN, C.H. and NIJHOUT, HF., (2004). Geographic variation of caste structure among ant populations. Current Biology, vol. 14, p. 514-519. 